Article

\title{
Environmental Recovery of Abandoned Mining Areas in Spain: Sustainability and New Landscapes in Some Case Studies
}

\author{
Carlos J. Pardo Abad \\ Department of Geography, Universidad Nacional de Educación a Distancia \\ (UNED), C/ Senda del Rey, 7, 28040 Madrid, Spain; Email: cjpardo@geo.uned.es
}

\begin{abstract}
The closure of open-cast mines has prompted the appearance of large, run-down and environmentally degraded spaces. Current legislation requires that such spaces, which mining marked so heavily over such long periods of time, must be restored. The measures adopted have such a wide-ranging territorial impact that they represent the creation of new landscapes in line with strict environmental sustainability criteria. Reducing slopes and banks, securing and decontaminating soils, filling the large mining holes and planting native plant species and crops have been the main solutions applied in the old mining areas. The black colour of the mines has been replaced by a new green colour in line with the natural environment, in a relatively recent and constant process that some authors relate to the concept of regenerative development, different but linked to the more traditional sustainable development. The analysis conducted in this research focuses on several Spanish cases that are highly representative, both nationally and internationally, of what the changes undertaken after mines are abandoned entail.
\end{abstract}

KEYWORDS: mining areas; sustainability; landscape; environmental recovery

\section{INTRODUCTION}

\section{G Open Access}

Received: 14 February 2019

Accepted: 30 April 2019

Published: 08 May 2019

Copyright (C) 2019 by the author(s). Licensee Hapres, London, United Kingdom. This is an open access article distributed under the terms and conditions of Creative Commons Attribution 4.0 International License.
In some of Spain's old mining operations, major environmental measures have been taken to recover the landscape after the mine was closed and abandoned. These landscapes were extraordinarily marked by a prolonged activity that left very deep scars, barely compatible with environmental and aesthetic sustainability criteria. The extraction of millions of tons of ore and earth generated prosperity and wealth in local communities, and guaranteed employment for a very important part of its population. However, mining also brought serious environmental problems, with damage that marked the landscape for decades.

After the mines were closed and abandoned, the authorities considered the possibility of implementing different recovery measures, with sustainable projects designed to restore the landscape and to improve the typical aesthetics of mining areas, which include big black 
holes, the result of the intense mining of the deposit, artificial hills with deposits of slag and leftover rocks, sharp slopes, heaps of differentcoloured earth and extensive areas devoid of vegetation.

The new restoration projects have created new and highly aesthetic landscapes and natural environments, with very rigorous sustainability criteria that guarantee the highest environmental quality standards. The old black landscapes have given way to green landscapes as a result of a firm and intense commitment to convert the impacts of the past into new future opportunities based on the technical wisdom and economic solvency that the projects applied represent.

The environmental restoration has gone hand in hand with a considerable cultural renovation. The huge variety and wealth of the heritage that mining has left us has promoted its conservation through various experiments for the cultural revaluation and historical recovery of buildings, machines, techniques and places. Numerous mining museums have opened in recent decades in developed countries, such as the Grand Hornu in Belgium, the industrial complex of the Zollverein coal mine in Germany, the mining area of Falun in Sweden, Riotinto in Spain and Lewarde in France. Reusing them for tourism has breathed new life into areas previously used for productive and extractive activities and that today are cultural and educational centres that preserve the memory of a past that is still not too distant.

Over and above the cultural or historical revaluation undertaken as part of these experiences, and of others in place in many countries, the recovery addressed in this research is a natural one-in other words, recovery aimed at restoring the natural environment that envelops the old mining space. We selected certain places in Spain that stand out due to the courses of action taken and the scale of the interventions.

The experiences selected are to be found in different parts of Spain, in areas with a mining tradition that has fallen into disuse in recent decades. In all of them, interesting environmental measures have been applied that have managed to recover extensive surface areas for nature. The case studies are as follows: Cerceda (Galicia), Almadén (Castile-La Mancha), Andorra (Aragón), As Pontes (Galicia), Peñarroya (Andalusia) and Puertollano (Castile-La Mancha). The only common denominator of these six different experiences is the environmental and sustainable restoration of old mining environments (Figure 1). 


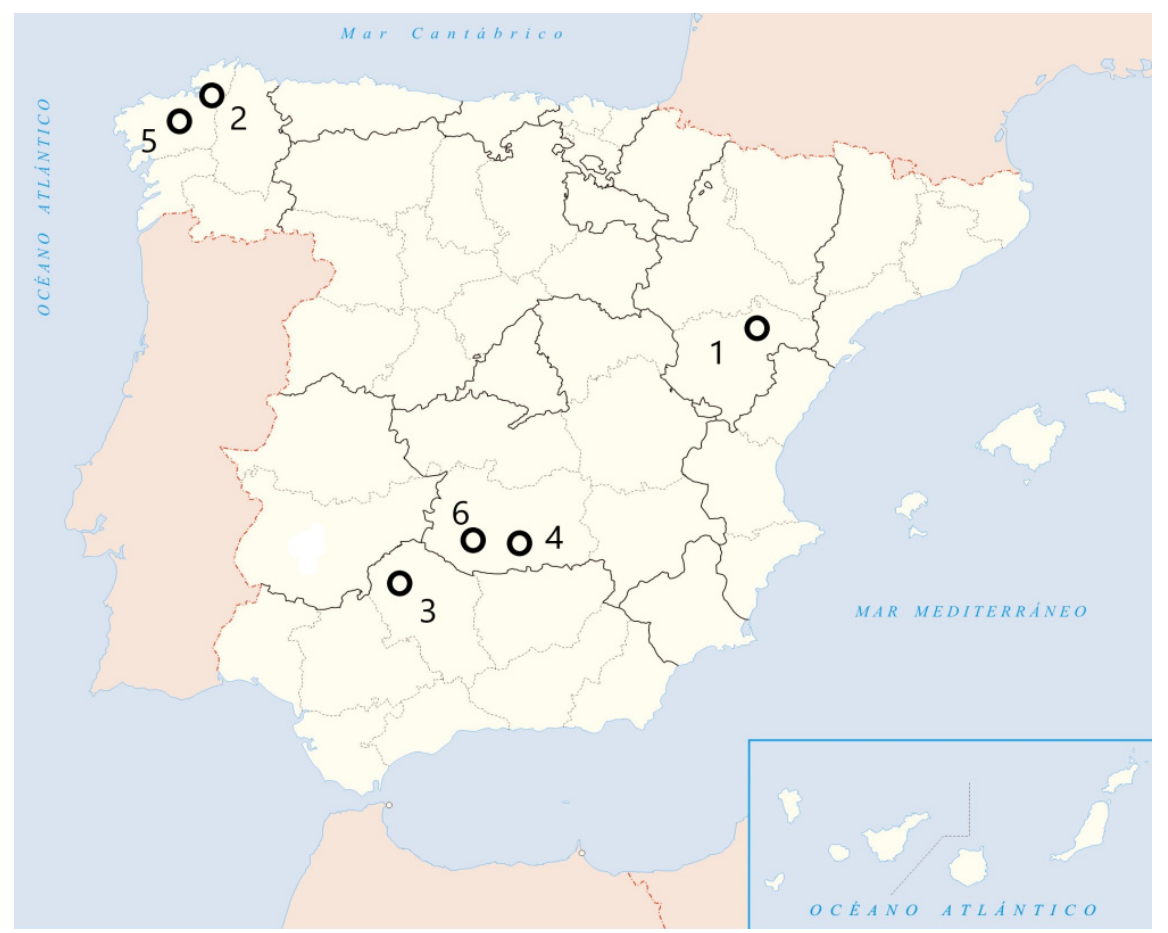

Figure 1. Location of the case studies: 1. Andorra; 2. As Pontes; 3. Peñarroya; 4. Puertollano; 5. Cerceda; 6. Almadén. Source: own elaboration.

The results are extraordinarily positive from the natural point of view, with the recovery of local flora and fauna, decontamination and treatment of soils, planting of land cover, construction of artificial lagoons, tree planting, etc. These are the most common ways of projecting sustainable models and disguising the environmental impacts derived from past uses and abuses. Each of them has produced a comprehensive and radical change that, in a short space of time, has managed to erase the very intense and harmful negative aesthetic impacts of the mining activities of the past.

Both Spain and the European Union have passed very strict laws to regulate the environmental impact of mining activities, with two key objectives: (i) respect for the environment by mining extraction; and (ii) the environmental recovery of the affected environment after the activity ceases. The high cost involved has made these two objectives very hard to meet, despite the increasingly demanding criteria applied by current legislation.

There is an abundant literature on the environmental recovery of abandoned mines. In recent decades, numerous articles and books have been published that are good references for reflecting on and analysing the main aspects of this topic. It is a very broad topic, with varied implications for some cross-cutting issues that are necessarily present in any environmental improvement and recovery process. There are numerous studies carried out from various disciplinary perspectives in which the approaches complement and enrich the vision of a problem increasingly studied in most countries. Broadly speaking, there are three 
different thematic blocks: (i) environmental recovery and legal implications; (ii) existing links with sustainable development; and (iii) the tourism value of the recovered mining areas.

Most authors regard abandoned mining areas as potentially hazardous spaces for nearby populations. This is the opinion of Belmonte, Romero and Moreno [1], who are very interested in analysing the health consequences of non-recovered mining lands. Other authors take a different approach, and generally are more interested in the characteristics of mining waste and the concrete conditions of rehabilitation of the affected areas. This is the general perspective provided by Rodríguez and García-Cortés [2], and also by Holl [3] in the United States; Zhang et al. [4] and Zhenqi, Peijun and Jing [5] in China; Fadda, Fiori and Matzuzzi [6] in Italy; and Conesa, Faz and Arnaldos [7] in Spain. These studies are of specific sites in these countries, but with important implications for other sites.

Other analyses are less locally focused, and address general theoretical and practical issues related to environmental recovery techniques. Most of this research focuses on soils and revegetation, as in the studies conducted by Sheoran, Sheoran and Poonia [8]; Dudka and Adriano [9]; and Venkateswarlu et al. [10]. Rehabilitation carried out on the basis of geomorphological design criterion has been the subject of fewer studies, but some of them point to the importance of a design based on the original relief as the best solution for the landscape and ecological rehabilitation of any natural environment affected by mining. This is the opinion of Martín et al. [11]. In some cases, the studies focus on the legal situation and its relationship with environmental conservation. This is a different approach within this first thematic block, yet complementary and of great interest because of the close links between legislation and the environment. This is the case of the analysis carried out by SEO Birdlife [12].

One highly interesting scientific approach studies environmental recovery as a lasting solution to the problems caused by prolonged extractive activity, thus linking it with sustainable development. This is the type of analysis carried out by the authors Carvajal and González [13] and Cole [14], who defend the need to apply compatible recovery processes with the inalienable objectives of sustainability.

Finally, the third thematic block studies abandoned mining areas as a very important tourist resource that must be emphasised, evidently, after the previous and necessary environmental recovery. There are many studies in this regard in all developed countries, such as those conducted by López and Vidal [15] in the abandoned mining area of Lota (Chile); by Cueto [16] in the Spanish region of Cantabria; and by Belmonte, Romero and Moreno [1] in Cartagena-La Unión (Spain).

The main aim of our research is to ascertain the real scope of environmental recovery actions in a series of very significant case studies in Spain with national and international impacts. In this regard, it 
is also worth mentioning some secondary objectives, hierarchically dependent on the main objective and, in turn, related to one another. They are as follows: (i) determine the characteristics of the landscape restoration and integration techniques; (ii) assess the ties existing between post-industrial landscapes and sustainability; and (iii) ascertain the most recent territorial dynamics of the restored former mining spaces.

\section{METHOD OF ANALYSIS}

As different countries, regions and localities exchanged and published their techniques, very similar models for harnessing natural resources began to emerge. This is why many mining areas share common features regarding the impacts of and proposals for intervention and recovery of the natural environment, the generalization of sustainable practices, the assessment and evaluation of environmental improvements or the introduction of new uses in the restored places. In any case, the fact that different places initially related to mining share common features does not prevent us from emphasizing the distinguishing characteristics of each site.

The study basically involved consulting different documentary, statistical and bibliographical sources. The publication of reports, based on the projects undertaken by the companies in charge of the environmental restoration, and consultation of news published in the press, have been two of the cornerstones of this analysis. The different courses of action have been compared with each other in order to ascertain the main environmental, socio-economic, technical and landscape features of each one.

The reports have shown the role played by the companies in charge of executing the projects, generally large energy utilities linked to the previous mining operation. This is the case of ENDESA and Naturgy (previously known as Gas Natural Fenosa). ENDESA was founded in 1944 as Empresa Nacional de Electricidad, S.A. This Spanish company operates in the electricity and gas sectors and is one of the country's leading electricity utilities. Naturgy operates in the same sectors as ENDESA did. It dates back to 1843, and in June 2018 Gas Natural Fenosa was renamed Naturgy. The telephone and in-person interviews of some of the people in charge of the restoration projects, and of local representatives of the municipalities involved, have provided first-hand information that is highly valuable due to the accuracy of the data collected.

One very important methodological aspect has been viewing aerial pictures of the restored areas to compare their characteristics before and after the environmental interventions. The size of the mining areas can only be grasped by using images of this kind, as well as large-scale cartographic interpretation for viewing features linked to the landscape. At all times, the fieldwork has gone hand-in-hand with the office work, 
providing first-hand knowledge of the areas selected for the study and resulting in an archive of highly valuable images.

The data about the analysed interventions have been checked by consulting aerial images and published maps of each zone and also through important fieldwork to check the validity of the technical reports and compare the recoveries with each other. This fieldwork has even served to verify, in situ, the achievement of small, secondary recovery and improvement tasks within the framework of the evaluation and environmental monitoring plans.

Direct map reading during the fieldwork phase revealed the real scope of the affected landscape and the partial or total recovery of the geomorphological forms, using maps published before the environmental rehabilitation. This work has been highly geographical and also a main aspect of the research due to the importance of the goal of returning the relief to its original shapes.

\section{ANALYSIS OF RESULTS: NEW LANDSCAPE AND SUSTAINABILITY}

Spain's strong mining history has had important impacts on the land. Over time, many of these mines were closed and abandoned after having been active for decades or centuries, and this abandonment led to degraded areas, aesthetically and environmentally unsustainable for the ecological and landscape balance, as Escribano maintains [17].

Abandoned mines are today a widespread feature of the coal mining industry because, under European Commission regulations, from 1st January 2019 any mines that need state aid to continue running cannot stay open. It is about reducing a highly polluting sector that is barely profitable due to the coal imported from other countries. The Spanish government's financial aid schemes to cope with the transition are designed, above all, to offer employment to the workers who have lost their jobs, through early retirement or creating job banks specifically aimed at undertaking the environmental restoration work over the coming years. New intervention projects, based on the success obtained in previous experiences, will be approved and new landscapes will replace the former mines.

The experiences already completed offer very interesting results from environmental and landscape perspectives. The projects have been implemented following recommendations in the form of a diagnosis, giving priority to protective, restoration and integration measures in the natural environment. Preserving mining-related industrial heritage has been given equal priority as an objective because of its historical and archaeological value. Consequently, the restoration and environmental management procedures have respected the legacy that mining has left over such a long period of time. Restoration of the degraded environment and conservation of the material heritage have been two basic and inalienable guidelines. 
The study presented here is conceived as a process of compiling data and experiences in several case-studies, selected because of their major importance and the scale of the interventions. Located in different regions of Spain, they are a group of environmental restoration projects with highly interesting results from the sustainability point of view. The degraded natural spaces have been regenerated in many ways, including through re-vegetation and reforestation measures. A total of 1,874,000 trees have been planted in the cases studied, showing the extent of the reforestation plan underway. In the old mining area of Puertollano, for example, 28,000 olive trees have been planted, producing an average of 230,000 kilograms of olives a year. In addition, the old mining holes (typical of open-pit mines) have been turned into artificial lakes, the soils have been cleaned of polluting agents, and wildlife has colonized the new retrieved spaces.

The results of these six environmental restoration experiences are comparable to those achieved in other abandoned mining areas. The benefits are not only environmental but also economic and social, because the projects applied have created new jobs and modernized the local economy. In some cases, new tourism opportunities have also emerged due to the creation of ecological rehabilitation interpretation centres, with routes joining the main attractions.

The surface area restored in the studied areas amounts to a total of 5670 hectares. Most of the mines were producing coal, although in Almadén the mineral obtained was cinnabar for the production of mercury. This mine was opened in the 3rd century BC and is the only one of its kind in the world that continued operating until the start of the 21st century, as it closed in 2003. In 2012, it was declared a World Heritage Site by UNESCO, as explained in Pardo [18].

In most of the cases, the environmental restoration projects ended a few years after the mines close, even though the rehabilitation tasks started before closure, as the mineral extraction advanced. These mines closed between 2003 and 2015, so the environmental actions are very recent experiences. They are backed by the example of other national and international actions and by the techniques applied in other mining tradition regions, in the opinion of Valenzuela, Palacios and Hidalgo [19]. The rehabilitation projects have been carried out by the energy utilities previously in charge of the mining operations, which has ensured better coordination of tasks and the achievement of environmental sustainability objectives. In $67 \%$ of the cases studied, the company in charge has been ENDESA, while Naturgy and MAYASA accounted for the other 33\%. The experience gleaned by ENDESA in intervening in abandoned mining areas makes it a great point of reference due to the uniqueness and scope of the processes carried out (Table 1). 
Table 1. Old mining areas and environmentally recovered elements.

\begin{tabular}{lllllll}
\hline $\begin{array}{l}\text { Mining area } \\
\text { (recovered element) }\end{array}$ & $\begin{array}{l}\text { Location } \\
\text { (province/region) }\end{array}$ & $\begin{array}{l}\text { Type of } \\
\text { extraction }\end{array}$ & $\begin{array}{l}\text { Start of } \\
\text { activity }\end{array}$ & $\begin{array}{l}\text { End of } \\
\text { activity }\end{array}$ & $\begin{array}{l}\text { Restored } \\
\text { surface } \\
\text { (hectares) }\end{array}$ & $\begin{array}{l}\text { Company } \\
\text { in charge }\end{array}$ \\
\hline $\begin{array}{l}\text { Andorra (4 open-cast } \\
\text { mines) }\end{array}$ & Teruel/Aragón & Coal & 1981 & 2012 & 865 & ENDESA \\
$\begin{array}{l}\text { As Pontes (As Pontes } \\
\text { mine) }\end{array}$ & La Coruña/Galicia & Coal & 1947 & 2007 & 2400 & ENDESA \\
$\begin{array}{l}\text { Peñarroya (7 open-cast } \\
\text { mines) }\end{array}$ & Córdoba/Andalusia & Coal & 1961 & 2010 & 835 & ENDESA \\
$\begin{array}{l}\text { Puertollano (Emma } \\
\text { mine) }\end{array}$ & $\begin{array}{l}\text { Ciudad Real/ } \\
\text { Castile-La Mancha }\end{array}$ & Coal & 1976 & 2015 & 560 & ENDESA \\
mine) & La Coruña/Galicia & Coal & 1980 & 2008 & 1000 & Naturgy \\
$\begin{array}{l}\text { Almadén (San Teodoro } \\
\text { waste rock) }\end{array}$ & $\begin{array}{l}\text { Ciudad Real/ } \\
\text { Castile-La Mancha }\end{array}$ & Cinnabar & $\begin{array}{l}3 r d \text { century } \\
\text { BC }\end{array}$ & 2003 & 10 & MAYASA \\
\hline
\end{tabular}

Source: ENDESA, Naturgy, MAYASA and own elaboration.

These environmental interventions represent a change of energy paradigm that has steadily moved from fossil fuels, which are highly polluting and degrade the natural environment, to renewable energies. This change has brought about another landscape change, as a consequence of the improvements introduced by the environmental interventions, under the protection of ever stricter legislation that promotes renaturation models to reproduce the original conditions in the most favourable way, according to Tempel [20].

Rehabilitation techniques have consisted in applying designs that are smoother-shapes than the originals, reducing the slopes to create more natural and harmonious environments. Some of the initial slopes, greater than $30^{\circ}$, from being reduced to an average of $18^{\circ}-20^{\circ}$. This has facilitated better landscape integration in all case studies: in the old Alloza mine, in Andorra (Teruel), the slopes have gone from $30^{\circ}$ to $20^{\circ}$, not only permitting the renaturation of the environment but also stopping soil erosion and allowing plant life to expand.

Slope reduction has stabilized the soils and has prevented any remaining metals or chemical compounds from being released into the environment. The oxidation of certain minerals can produce undesired acidic conditions, and the solution has been to add lime to neutralize the acidity and restore a layer of organic soil. Solutions that may seem very simple, but that have been very effective in all cases.

In rehabilitating the old mines, rectilinear shapes have been avoided to prevent the appearance of ravines. Geomorphological guidelines have been applied, repeating the natural landscapes of the action areas. Many holes have been filled with water to create artificial lakes and allow plant 
and animal reproduction, and other holes have been filled with the mineral waste itself, with a restoration proposal based, in this case, on the topographic reconstruction.

The environmental recovery of the selected old mining areas is closely related to the climatic and edaphic conditions of the area. In general, annual rainfall is scarce, less than $600 \mathrm{~mm}$, and the average temperature values are suitable for any agricultural or forestry plant growth. Forest suitability is more important in the two studied zones of Galicia, where the environmental recovery has focused on tree revegetation. In the other cases, both forestry and agricultural interventions have been applied because the soils were better suited to the crops (Table 2).

Table 2. Climatic and edaphic data of the recovered mining areas.

\begin{tabular}{|c|c|c|c|c|}
\hline $\begin{array}{l}\text { Mining area } \\
\text { (province/región) }\end{array}$ & $\begin{array}{l}\text { Average } \\
\text { anual rainfall } \\
(\mathrm{mm})\end{array}$ & $\begin{array}{l}\text { Average } \\
\text { anual } \\
\text { temperature } \\
\left({ }^{\circ} \mathrm{C}\right)\end{array}$ & $\begin{array}{l}\text { Climatic } \\
\text { zone } \\
\text { classification } \\
\text { (Köppen) }\end{array}$ & $\begin{array}{l}\text { Soil classification } \\
\text { (aptitude) }\end{array}$ \\
\hline Andorra (Teruel/Aragón) & 378 & 12.2 & Bsk & Aridisols (low fertility) \\
\hline As Pontes (La Coruña/Galicia) & 1014 & 14.8 & $\mathrm{Csb}$ & Entisols (forestry aptitude) \\
\hline Peñarroya (Córdoba/Andalusia) & 605 & 15.1 & Csa & Inceptisols (high fertility) \\
\hline $\begin{array}{l}\text { Puertollano (Ciudad } \\
\text { Real/Castile-La Mancha) }\end{array}$ & 501 & 15.6 & Csa & Inceptisols (high fertility) \\
\hline Cerceda (La Coruña/Galicia) & 1050 & 14.6 & $\mathrm{Csb}$ & Entisols (forestry aptitude) \\
\hline $\begin{array}{l}\text { Almadén (Ciudad Real/Castile- } \\
\text { La Mancha) }\end{array}$ & 510 & 15.6 & Csa & Inceptisols (high fertility) \\
\hline
\end{tabular}

Source: Agencia Española de Meteorología, Soil Taxonomy classification by the Soil Survey Staff of USA and own elaboration.

The post-mining situations vary greatly from one mining area to another. Basically they depend on the companies' and public authorities' commitment to boost the local economy, restore environmental damage, encourage tourism and create a new productive structure underpinned by the tertiary sector. Tourism is usually one of the best postabandonment options, but Jansen-Verbeke [21] argues that it first involves restoring the environment to allow visits and eliminate any remaining contamination.

The province of Ciudad Real is home to the old Almadén mines, a fine example of environmental rehabilitation and new tourist usage. The mines were located in the biggest cinnabar deposit in the world. Mining began in ancient times with the Romans and then continued with the Arabs. The boom started from the 16th century onwards, when mercury became essential for amalgamating silver, mined in large quantities from South American deposits. From then on, mines were linked to the State.

After a decline in the 17th century, mining production rose again in the 18th century. In the 19th century the mines were mortgaged, and the 
monopoly was awarded to several foreign entrepreneurs, who boosted production that ended up peaking in the mid-20th century. As a result of a decline in consumption and shrinking mineable reserves, the mines ceased to be profitable from then on. After the mine was finally closed in 2003 and a decision was made to recover it for tourism purposes, the area has become one of Spain's cultural points of reference and known as the Almadén Mining Park, as explained by Pardo [18].

Several items of the mining complex have been protected since 1992 as Assets of Cultural Interest. In 2007, the mines were declared a Historic Site by the regional government of Castile-La Mancha. In 2012, they were included on the UNESCO World Heritage list in recognition of their value as the largest cinnabar mines in the world and a unique example of continued mining over the centuries. The total area currently protected is 104 hectares.

After the definitive closure, the authorities sought to minimize the environmental impacts. In 2004, a project was designed to rehabilitate the San Teodoro waste rock disposal area, which for centuries was used to dump the waste material from the mining activities and the waste products of the metallurgical processes. It covered a surface area of almost 10 hectares and stored 3.5 million tonnes of materials hazardous due to their mercury content (Figure 2).

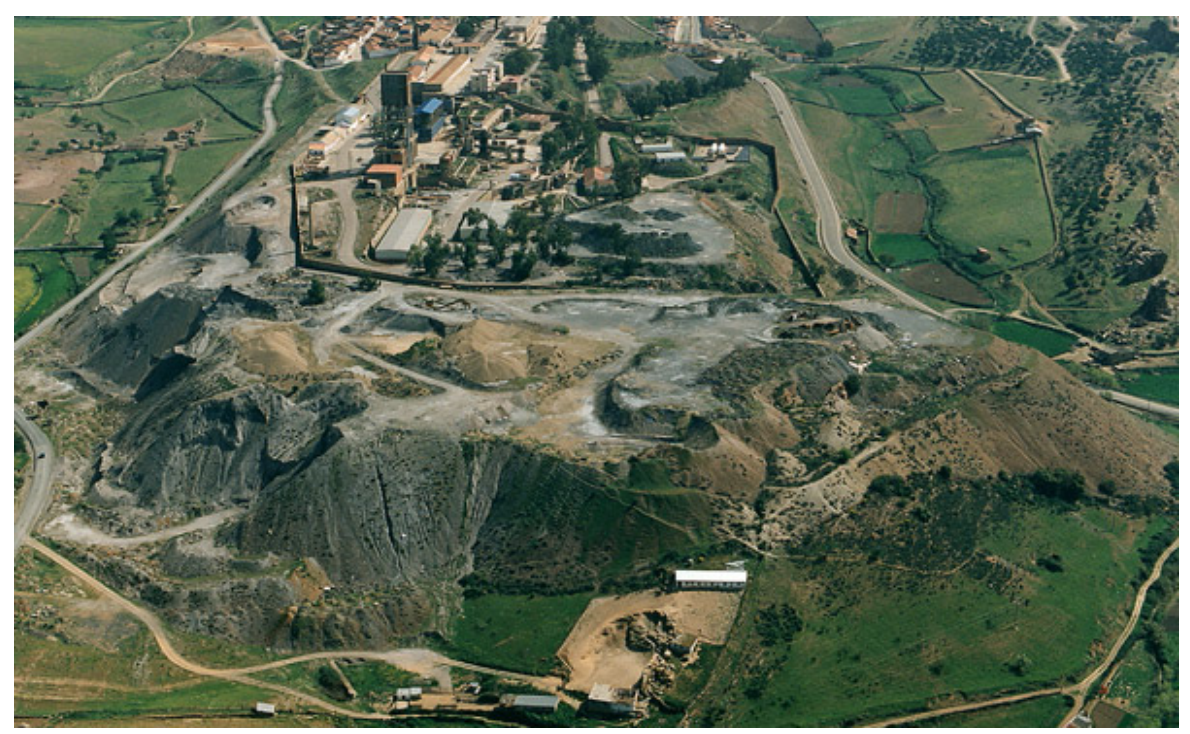

Figure 2. Waste rock of the mining area of Almadén before rehabilitation (2005). Source: Paisajes Españoles.

The rehabilitation consisted of encapsulating the heap to guarantee its stability and waterproofing (Figure 3). The gradient of the existing slopes has also been reduced to ensure that they blend in with the natural slopes of the area, from the $36^{\circ}$ initial slope to the current $25^{\circ}$. The land cover has been restored to merge the structures better into the landscape, using autochthonous, fast-growing species to reduce erosion as soon as possible. 


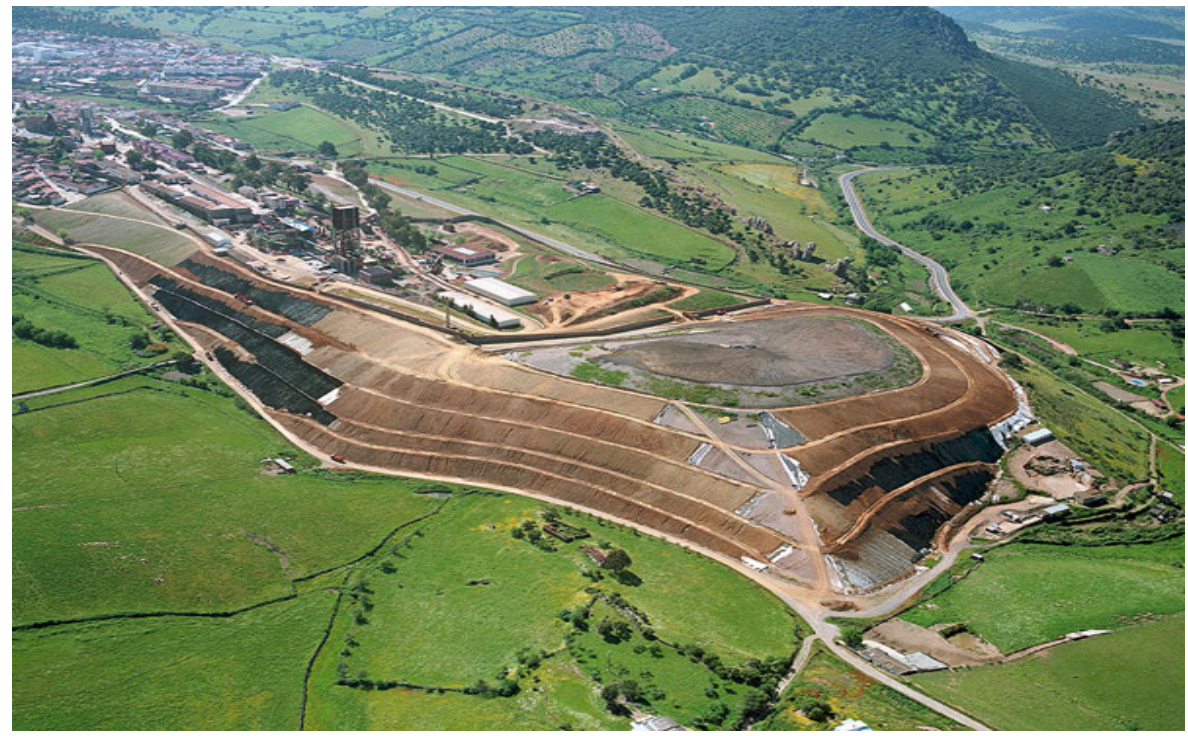

Figure 3. Waste rock of the mining area of Almadén in the rehabilitation phase (2007). Source: Paisajes Españoles.

Also located in the province of Ciudad Real is the Puertollano mining area. This coal mining valley was discovered in 1873 and regular production began in 1883 . For nearly a century, the coal was mined underground by several different foreign and Spanish concessionaires. In 1976, open-pit mining began in the Emma pit, with the objective of supplying fuel to the Puertollano thermal power plant. The coal mining industry regulations and the slump in demand marked the final evolution of the pit and its final closure in 2015.

During its years of activity, it produced 25 million tons of coal and more than 350 million cubic metres of earth were moved. The pit was mined by the tailings transfer method. In other words, first the materials covering the coal beds were extracted, then they were deposited in the surrounding area as waste rock and, lastly, these materials were used to cover the hole in the ground. This process continued in successive stages, uncovering and mining the coal beds, so the mine advanced all along the deposit.

For this reason, the Emma Mine Restoration Plan dates back to 1985. This is when the environmental restoration work began on the affected lands. The aim was to strike a balance between using the remaining coal and recovering the environment in a sustainable manner. (It should be noted that the environmental restoration of the land in the Emma Pit in Puertollano occurred before the enforcement of Royal Decree 1994/1982 on the restoration of the natural space affected by mining activities and, therefore, prior to any legal requirement.) Through a combination of appropriate restoration techniques, proper design and suitable soil characteristics, the resulting waste rock was integrated with the landscape and new crops, pastures and native vegetation now grow on them. The ecological value of the intervention, therefore, is very high. 
A total of 560 hectares of land has been restored, of which 244 hectares are used for grassland and cereal crops, 126 hectares for olive groves, 9 hectares for fruit trees and 77 hectares for Mediterranean trees. Thirty-four hectares have been turned into a mining lake, 27 hectares have been reforested with autochthonous species and the remaining 43 hectares are occupied by permanent road infrastructure.

The Meirama mine, in the municipality of Cerceda (La Coruña), opened in 1980 and closed in 2008 after the reserves were exhausted. During this period, it supplied more than 90 million tons of coal to the thermal power plant located in the vicinity of the mine, leaving a huge hole 300-metres deep.

When it was closed, it was clear that the site needed environmental restoration. Back in 1985, the company had already launched the first project with various planned actions and strict sustainability criteria. In other words, while it was mining the pit, it started working on the future restoration of external waste rock, with enormous amounts of earth and ash deposits.

The rehabilitation of the Cerceda mine (La Coruña) has consisted of a comprehensive reordering of the affected territory, with the introduction of rational uses from the economic, environmental and social point of view. The intervention has focused on the geomorphological treatment of waste rock, the establishment of a stable and diversified plant cover and the creation of an artificial lake in the old mining pit.

Waste rock restoration has been the priority, reducing the slopes by $30 \%$ and also reducing artificial geometric shapes. After this first phase, the land was prepared for revegetation, with a new topographic configuration, treatment of the topsoil, edaphic corrections and the contribution of a mixture of seeds with complementary characteristics.

In the old pit a very large artificial lake has been created. In 2016 the filling of the lake was finished, and both the excellent quality of its water and its strategic position at the top of a river basin turned it into the future water reservoir for the city of La Coruña and its region after the approval of the pertinent water regulation and control project.

The lake takes centre stage in this new landscape, and these figures show just how spectacular the action taken was: 147 cubic hectometres in volume; a maximum of 2218 metres long; a maximum of 1011 metres wide; 2218 hectare sheet of water; and a maximum of 205 metres deep (Figure 4). Today there is no trace of its mining history, except some old machinery that is kept in the surroundings as a tribute and memory. 


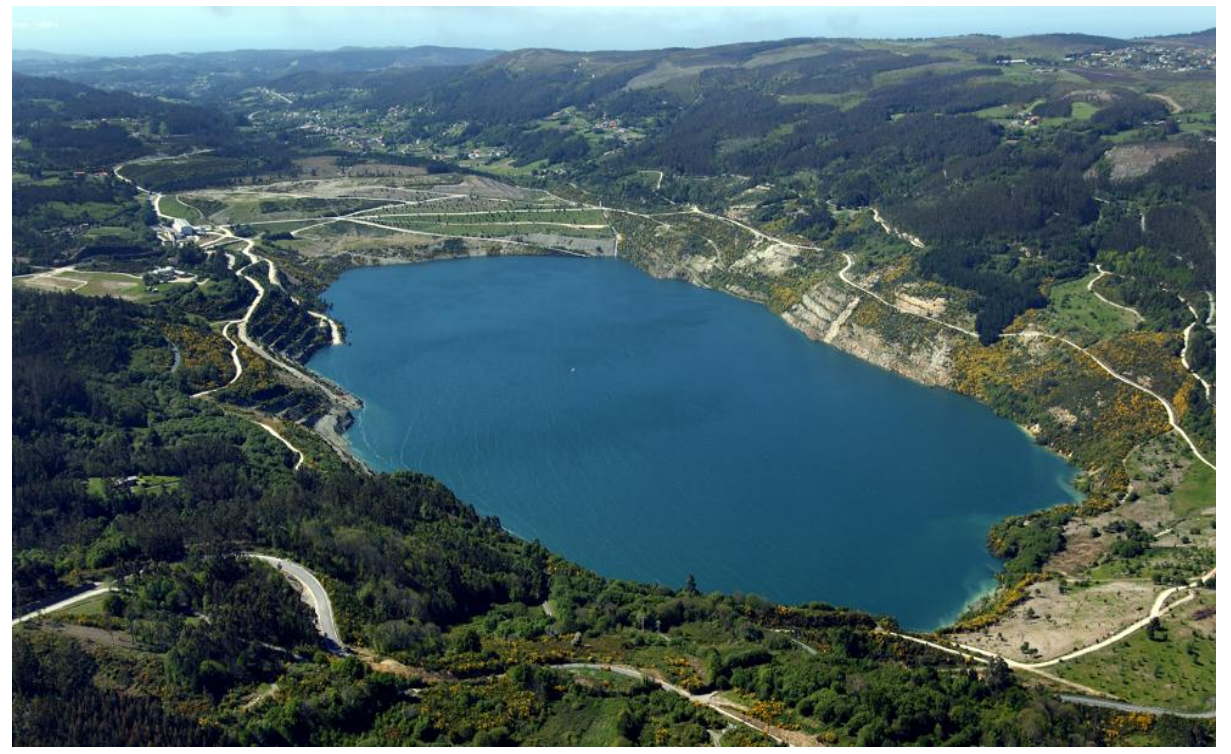

Figure 4. Meirama lake in the old Cerceda mine. Source: Paisajes Españoles.

The presence of mining resources in the area of As Pontes, in the province of La Coruña, was known since ancient times, although the first written documents date back to the 18th century. Large-scale coal mining began in the 1940s, and the ENDESA mining complex was built in 1972. The mine became the largest open-pit mining operation in Spain, and a landmark in the area because of its huge size and profound repercussions on the surrounding territory (Figure 5).

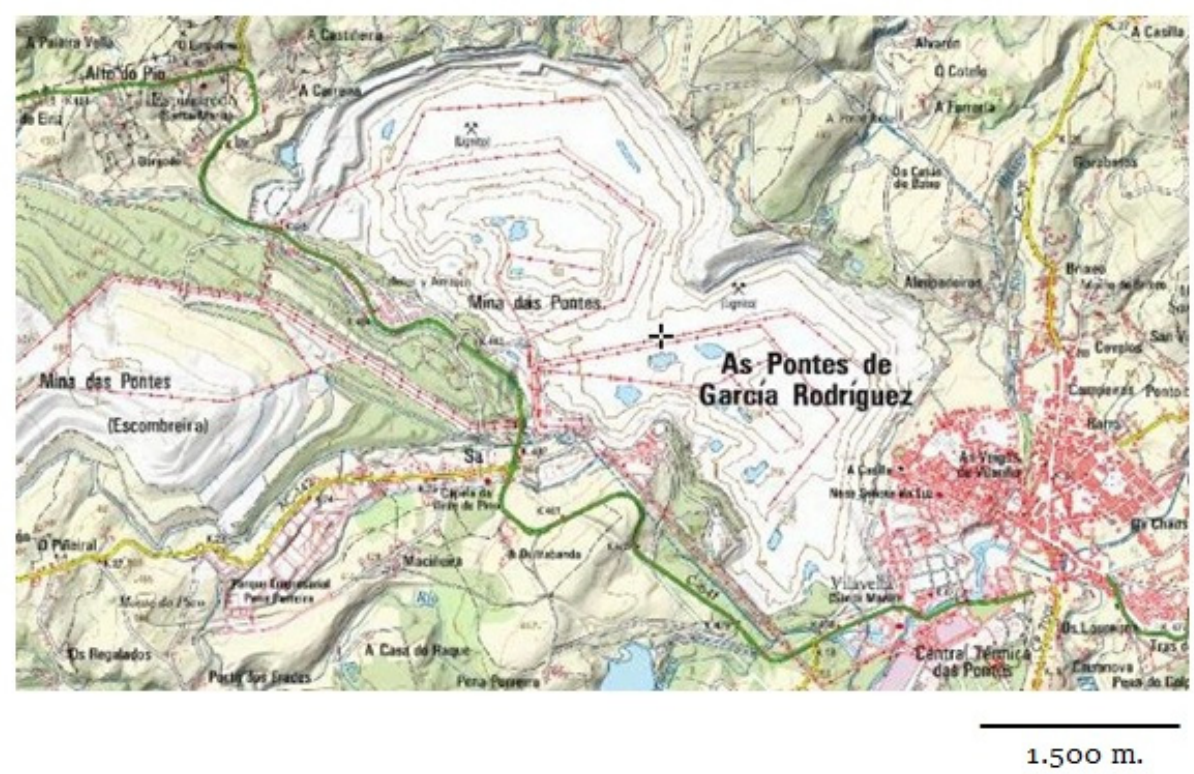

Figure 5. As Pontes mining area before rehabilitation. Source: Instituto Geográfico Nacional.

Coal extraction ceased permanently in 2007 and the controlled flooding of the pit lasted from 2008 to 2012. This gave rise to one of the largest artificial lakes on the continent, containing a total volume of 547 cubic hectometres, with 865 hectares of water sheet (Figure 6). 


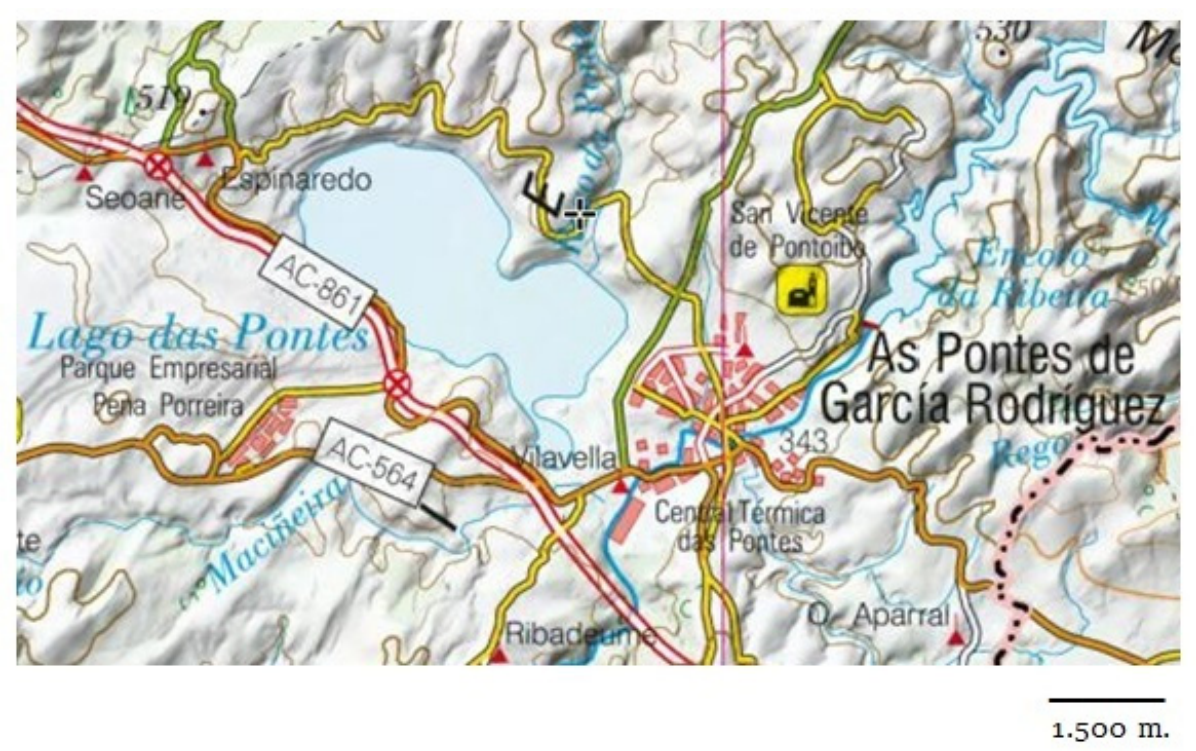

Figure 6. As Pontes mining area after rehabilitation. Source: Instituto Geográfico Nacional.

This pit represents an extraordinary example of environmental recovery, not only because of the artificial lake but also because of the work carried out on the old external waste rock, with huge amounts of sterile waste accumulated at successive levels. In 1985, the company designed a restoration programme for this external waste rock, consisting in the creation of a stable plant cover and the repair of the landscape, which had been so heavily impacted by several decades of intense mining operations. Initially, the environmental programme continued to coexist with the mining activity itself, intervening selectively in certain areas. Today the old waste rock has become a highly valuable ecological habitat, with more than 180 different species of vertebrate animals, about 600,000 trees and areas of grasslands, shrubs and wetlands.

The restoration of the As Pontes mine has given rise to a large sustainable ecosystem, integrated harmonically into the traditional natural environment of the Galician mountains, and capable of regenerating itself. In addition, new opportunities for local economic development and new leisure and tourist attractions have been created.

The Peñarroya mining complex, in the province of Cordoba, was discovered in the 18th century, but large-scale mining started off in the 19th century in the wake of the lead metallurgy boom and the incipient railway-building. Mining activities were stepped up even more in the 20th century and in 1961 the mine was taken over by the state-owned company ENDESA, until it closed in 2010.

The mining was underground and open-pit, with a fairly high number of facilities. The open-pit mining produced large amounts of tailings, with a huge visual and landscape impact. The restoration techniques applied, as in the aforementioned cases, have managed to minimize the environmental damages. To allow the natural environment to regenerate 
itself, these interventions have been underpinned by several principles of sustainable development: (i) generate stable land surfaces; (ii) create spaces integrated into the natural landscape; and (iii) re-establish the productive function of the pre-existing ecosystem.

The restoration of the waste rock and mines has consisted of adapting the soils, planting herbaceous, shrub and native tree species and turning the pits into artificial lakes and a home for aquatic wildlife. The individual surface area of each lake is smaller than that of the lakes of other abandoned mines, but together they represent a very interesting set of lakes. The intervention, in which 835 hectares were restored, has affected a total of seven open pit mines.

The last case study is the Andorra mining complex, in the province of Teruel. Coal was already being mined in the 18th century, although the geographic distance from its main centres of consumption conditioned its development. The railway connection with Zaragoza in the 20th century prompted mineral production, as well as increasing industrialization.

The opening of the Alloza mine, in 1981, heralded the start of opencast mining and the steady replacement of underground mining. Production rose, costs and the workforce dropped and environmental impacts increased. The European regulations approved from 1990 onwards to streamline the coal mining industry triggered a decline in mining in the region and the last mines were closed in 2012.

The approach to waste rock has evolved in several phases. At first, straight lines and steep slopes predominated. The result was a very artificial aesthetic that barely blended in with the surrounding landscape. From 1986 onwards, this kind of waste rock deposit was replaced by a different model based on slopes that were not so steep and smoothershaped, allowing them to blend into their surroundings better. In the last phase, it was decided to use the newly-created surfaces for new purposes, such as growing cereal crops, fruit trees, olive trees or vineyards and tree and shrub species. In addition, 38 hectares of wetlands were created in the abandoned mines. A total area of 865 hectares has been restored.

One of the key features of this restored area is that there is an environmental interpretation centre that explains the work that used to be done in the old mines. All along the seven-kilometre guided tour are several viewpoints from which to contemplate the scope and the end result of the rehabilitation work carried out. This is an example of an excellent combination of environmental reclamation and tourism.

The Bay of Portmán, in the Region of Murcia, is another exceptional example of environmental recovery that is underway. The filling of the area, with the mining waste accumulated between 1959 and 1990, was one of the country's greatest environmental disasters. During this period, 60 million tons of mining remains were dumped into the sea, filling a total of 75 hectares. The final result sought is to recover the former coastline, design a sustainable tourism development plan and encourage 
the participation of the local population, in the opinion of Banos-González et al. [22].

The general principles of intervention coincide, in general terms, with the other cases previously analyzed, prioritizing the restoration of the natural environment to its original state and eliminating the impact caused by prolonged mining activity. All these cases raise the environmental legislation issue. Spanish mining-related environmental legislation was the first of its kind. In 1973, the Government passed a law (still in force) that sought to solve the environmental problems created by mining. Companies failed to comply with many of the regulations, so subsequently other complementary measures were approved: the mining company's obligation to draw up an Environmental Restoration Plan (1982) and the obligation to use mining resources rationally (1984).

These measures require restoring the affected soil and guaranteeing that the restoration work is carried out by the mining company. Subsequently, the laws on Environmental Impact Assessment (1986) and on Regulations for the Implementation of the Environmental Impact Assessment (1988) regulated the administrative procedure in accordance with European guidelines on this subject.

In general, mining activity has been one of the main objectives of Spanish environmental conservation policy. The laws have been updated in line with successive European legislation. In 2004, the European Union developed the Document on Best Available Techniques for Management of Tailing and Waste Rock in Mining Activities; and then in 2006 definitively passed the Directive on Management of Waste from Extractive Industries. This Directive was applied by the various Member States between 2008 and 2014, and was monitored very strictly because $30 \%$ of all waste in the European Union is from extractive operations.

In Spain, the restoration of the areas affected by mining was again regulated in 2009 and 2012. These regulations did not differ very much from those previously in force. In principle, they oblige the mining company to draw up Restoration Plans before it can obtain a mining permit. However, they do not impose the necessary guarantees, which is why there are numerous (non-quantified) breaches.

The recovery of old mining areas, in the cases analysed and in others in Spain and Europe, represents a highly significant environmental commitment. For a very long time, open-cast mines scarred natural landscapes with all their forms and contents. The result was sacralised in the form of mineral resources necessary for industrialization and the sites and territories were sacrificed unscrupulously.

The land's interior was emptied of the desired resources, and the vegetation and animal life on the surface; the landscape and its forms; and the land uses and living spaces of human beings, were seriously altered. The extent of the damage was very large, and so large that opencast mining is one of Spain's top environmental impacts. 
The damage can never be corrected completely because it is impossible to return the territory to its original state. The measures applied in all the studied areas can be classified as sublime from the ethical point of view and very precise from the technical point of view. Yet what is missing is the complete aesthetic scope of what the landscapes were before the mining activity.

Nevertheless, recovery processes are the essential basis for nature to start healing and, over time, for new opportunities to emerge from the previous devastation. The creative imagination applied in recovering the degraded landscape plays a decisive role in this process and must be acknowledged, together with the enormous economic and technical efforts made in each case. The environmental projects have been the result of a great collective enthusiasm involving intense emotions; and the natural instructions of the climate and soils of each site have helped in all cases to initiate a timely and adequate regeneration that places value on the previous and current landscape to turn it into a heritage resource in the future.

Converting large black pits into lagoons, such as in As Pontes and Cerceda, accumulating inert waste in olive groves, grain fields or groves is a satisfactory result in areas damaged by a heavy mining past. From that point on, nature and life know how to do the rest.

\section{DISCUSSION OF RESULTS: A REGENERATIVE DEVELOPMENT MODEL?}

The restoration of abandoned mining areas features two profoundly geographical interpretive elements: the territory and the environment. Mining landscapes are directly related to these aspects, to which one might also add the time factor, which is essential for ascertaining the true extent of the impacts generated after decades or centuries of nonstop activity.

Following the closure of the mines, environmental recovery work has probably weighed far more than the preservation of the material heritage in the fate of former mining sites. In the opinion of Pardo [23], this has been the most usual way of designing the sustainable models that are sought and disguising the cumulative effects derived from the uses (and abuses) of the areas in question.

Returning the landscape to its natural state has been considered essential, except when the chromatic variety of the earths, the shapes and cavities left by mining operations and the mineral remains are factors that represent tourist attractions. This is what Okada considers [24], and what has happened in the mining area of Riotinto (Andalusia), which is one of the world's most spectacular post-industrial landscapes. The upturn in domestic and international tourism points to the interest in the values of these spectacular landscapes.

Yet environmental recovery and landscape restoration work have been the main interventions taken after mining activity ceased. Ecological footprints are not always acceptable, which is why the impacts 
generated on the territory have to be erased. A sort of environmental aesthetic surgery that conforms to Spanish and European legislation and assumes the principles associated with sustainability, as identified by Hauser [25].

That sustainable scenic development is defined by large-scale interventions, also identified by Lin [26] because of their emotional and identity-related repercussions on local communities. What one should wonder is whether erasing the traces of mining history also erases the emotional traces of the place's inhabitants and workers.

How is it possible to maintain these features in a lasting manner if, in essence, the activity that generated them is ephemeral? This is the dilemma that affects any mining legacy. Society must become involved in looking for solutions and any measure that harms nature and its ecosystems must be avoided. Some authors defend the idea that landscapes must be preserved as sedimented history, as a visual document of a story of conflict, according to Tempel [20]. Others, like Edwards and Llurdés [27], argue in favour of maintaining what they call the "aesthetic of de-industrialization" as a value per se, which regenerates the old mining territory on economic bases defined by heritage-based cultural tourism.

Overcoming environmental difficulties in the old mines is a concrete form of sustainable recovery of the natural environment. The measures adopted might go beyond the concept of sustainable development and instead represent what is defined as regenerative development. Basically it means that the undesirable traces of mining history are made to disappear, giving way to new ecological possibilities capable of improving present and future conditions for society. Creating artificial lakes is one example, thanks to the opportunities to supply top-quality drinking water to nearby towns and villages and regulate watercourses. Creating new fields for growing crops is another example.

One of the basic principles of this regenerative development is that it reconnects people with the spaces in which they live, and thus plays an important role in their physical identification and their relationship with nature. These complex dynamics provide environmental certainty for mitigating the changes and alterations caused by past human activities, according to Mang and Haggard [28] and Gibbons et al. [29]. From a theoretical and practical perspective, operations to restore old abandoned mines could fit this line of argument. It would involve extending the sustainable approach with the contributions of the regenerative development concept, i.e., recovering the natural environment and the social environment at the same time, in a relationship of predictable and controllable mutual benefit and reciprocity. 


\section{CONCLUSIONS}

Abandoned mines have provided an exceptional opportunity to intervene in areas that were mined for long periods of time. The size of the areas in question, the application of the strictest sustainability criteria and the appearance of new landscapes in accordance with the natural environment and its ecosystems make them highlights of sustainable environmental recovery in action.

The measures to restore abandoned open-cast mines have a scope that is undeniably territorial and, therefore, geographical, and their analysis points to the size and complexity of the actions taken. Erasing such deep traces and marks is no easy task. On the contrary, it is a very complex task, but restoration techniques have reached such a very high level as to permit the sustainable recovery of environments and minimize environmental effects. The results are very evident from the visual and aesthetic viewpoint, with restoration work subject strictly to the applicable legal requirements and oriented to facilitate new agricultural, livestock, forestry or tourism uses.

In all the cases analysed, restoring abandoned mining areas has comprised a series of operations consisting of ensuring the landscape integration of the old waste rock; improving the soil characteristics to sustain animal or plant life in the form of crops, pastures or autochthonous vegetation; filling the subsided areas and cavities of the old open-strip mines by creating artificial lakes in some of the restoration projects that in themselves represent major environmental engineering achievements; and smoothing out banks and slopes to make the land more stable and facilitate farming and agricultural work.

The cases analysed have been selected because of the spectacular nature of the results. They are a representative sample of a very technically complex process that nearly always starts before the pit is finally abandoned and lasts beyond its closure until it is environmentally restored. There are more cases of interventions in Spain, with just as significant results, as well as in other European countries. The forced closure of state-funded coal mines in 2019, in line with European Union regulations, means that the legal requirement to environmentally restore the abandoned areas will remain in force, attracting much attention both in technical and scientific terms and in the news.

Local communities are affected in several ways. Sometimes they are affected by nostalgia, as they have lost a past related to mines. At other times, the effects are economic, due to the loss of jobs. Yet these developments also should be viewed from the perspective of the new environmental, labour and tourist opportunities associated with them. This is evidenced by the results outlined in this research. Certain sustainable and/or regenerative interventions can push up the value of the abandoned land and turn it into an instrument for recovering a social environment that was very hard hit by the industry's crisis. 
This topic has been frequently analysed from the technical or environmental point of view, in relation to the recovery instruments applied and the results that have been obtained. The tourist use of rehabilitated mining territories is a pending task and represents a challenge of undoubted scientific value. The increasing "touristification" of the most varied spaces and resources justifies their study and plays a major economic and social role in local communities. Employment creation, the reinforcement of identity-related symbols and the heritagerelated conversion of the inherited territorial resources are some very important objectives to take into account.

Future environmental interventions must necessarily consider these tourism and sustainability-related aspects, with sustainable tourism that attracts tourists to these interior areas from the main tourist routes. In short, new incentives are needed to keep active the memory of the past with projects that stimulate local development in the near future.

\section{CONFLICTS OF INTEREST}

The author declares no conflict of interest.

\section{REFERENCES}

1. Belmonte F, Romero A, Moreno J. Contaminación ambiental por estériles mineros en un espacio turístico en desarrollo, la Sierra Minera de Cartagena-La Unión (Sureste de España). Cuadernos de Turismo. 2010;25: 11-24. Spanish.

2. Rodríguez R, García-Cortés A. Los residuos minero-metalúrgicos en el medio ambiente. Madrid (Spain): Instituto Geológico y Minero de España; 2006.

3. Holl KD. Long-term vegetation recovery on reclaimed coal surface mines in the eastern USA. J Appl Ecol. 2002;39(6):960-70. doi: 10.1046/j.1365-2664. 2002.00767.x

4. Zhang Y, Yang J, Wu H, Shi C, Zhang C, Li D, et al. Dynamic changes in soil and vegetation during varying ecological-recovery conditions of abandoned mines in Beijing. Ecol Eng. 2014;73:676-83. doi: 10.1016/j.ecoleng.2014.09.113

5. Zhenqi H, Peijun W, Jing L. Ecological Restoration of Abandoned Mine Land in China. J Resour Ecol. 2012;3(4):289-96. doi: 105814/j.issn.1674-764x. 2012.04.001

6. Fadda S, Fiori M, Matzuzzi C. Developing rehabilitation design for the abandoned mine excavations in Central Sardinia, Italy. Int J Min Reclam Environ. 2010;24(4):286-306. doi: 10.1080/17480931003775607

7. Conesa HM, Faz A, Arnaldos R. Heavy metal accumulation and tolerance in plants from mine tailings of the semiarid Cartagena-La Unión mining district (SE Spain). Sci Total Environ. 2006;366:1-11. doi: 10.1016/ j.scitotenv.2005.12.008

8. Sheoran V, Sheoran AS, Poonia P. Soil Reclamation of Abandoned Mine Land by Revegetation: A Review. Int J Soil Sediment Water. 2010;3(2):1-20. doi: scholarworks.umass.edu//intljssw/vol3/iss2/13 
9. Dudka S, Adriano DC. Environment Impacts of Metal Ore Mining and Processing: A Review. J Environ Qual. 1997;26(3):590-602. doi: 10.2134/ jeq1997.00472425002600030003x

10. Venkateswarlu K, Nirola R, Kuppusamy S, Thavamani P, Naidu R, Megharaj M. Abandoned metalliferous mines: ecological impacts and potential approaches for reclamation. Rev Environ Sci Biotechnol. 2016;15(2):327-54. doi: 10.1007/s11157-016-9398-6

11. Martín Duque JF, Pedraza J, D’ez A, Sanz MA, Carrasco RM. A geomorphological design for the rehabilitation of an abandoned sand quarry in central Spain. Landsc Urban Plan. 1998;42(1):1-14. doi: 10.1016/S0169-2046(98)00070-X

12. SEO Birdlife. La situación legal de la minería en España y su relación con la conservación ambiental. Available from: http://www.seo.org/wpcontent/uploads/2018/04/Informe-Ley-de-Minas_SEO_BirdLife.pdf. Accessed 2019 Mar 7.

13. Carvajal DJ, González A. El papel de los parques y museos mineros en el desarrollo sostenible. Re Metallica. 2003;1:26-36. Spanish.

14. Cole D. Exploring the Sustainability of Mining Heritage Tourism. J Sustain Tour. 2004;12(6):480-94. doi: 10.1080/09669580408667250

15. López MI, Vidal C. Paisaje patrimonial y riesgo ambiental. Reocupación cultural y turística del espacio postminero en Lota, Chile. Revista de Geografía Norte Grande. 2012;52:145-65. Spanish. doi: 10.4067/s071834022012000200009

16. Cueto GJ. Reutilización turística del patrimonio minero de Cantabria. Cuadernos de Turismo. 2009;23:69-87. Spanish.

17. Escribano MM. Los espacios mineros abandonados. El caso de la Comunidad de Madrid [dissertation]. Madrid (Spain): Universidad Politécnica de Madrid; 2015. Spanish.

18. Pardo CJ. The post-industrial landscapes of Riotinto and Almadén, Spain: scenic value, heritage and sustainable tourism. J Herit Tourism. 2017;12(4):331-46. doi:10.1080/1743873X.2016.1187149

19. Valenzuela M, Palacios AJ, Hidalgo C. La valorización turística del patrimonio minero en entornos rurales desfavorecidos. Actores y experiencias. Cuadernos de Turismo. 2008;22:231-60. Spanish.

20. Tempel N. Post-industrial landscapes. In: Douet J, editor. Industrial Heritage Re-tooled. Lancaster (UK): Carnegie Publishing Ltd.; 2012. p. 142-8.

21. Jansen-Verbeke M. Industrial heritage: a nexus for sustainable tourism development. Tourism Geographies. 1999;1(1):70-85.

22. Banos-González I, Baños Páez P, Pérez-Cutillas P, Esteve Selma MA. Análisis de las propuestas de los actores sociales en 1 recuperación ambiental de la bahía de Portmán (Región de Murcia). Nuevas perspectivas para un desarrollo sostenible. Cuadernos de Turismo. 2017;40:135-54. Spanish. doi: 10.6018/turismo.40.309641

23. Pardo CJ. Sostenibilidad y turismo en los paisajes culturales de la industrialización. Arbor. 2017;193(785):a400. Spanish. doi: 10.3989/arbor. 2017.785n3006 
24. Okada M. Industrial ruins. In: Douet J, editor. Industrial Heritage Re-tooled. Lancaster (UK): Carnegie Publishing Ltd.; 2012. p. 149-54.

25. Hauser S. Metamorphosen des Abfalls. Konzepte für alte Industrieareale. Frankfurt (Germany): Campus; 2001. Germany.

26. Lin HW. Conservation and community consciousness. In: Douet J, editor. Industrial Heritage Re-tooled. Lancaster (UK): Carnegie Publishing Ltd.; 2012. p. 155-60.

27. Edwards JA, Llurdés JC. Mines and quarries: industrial heritage tourism. Ann Tourism Res. 1996;23(2):341-62.

28. Mang P, Haggard B. Regenerative Development and Design: A Framework for Evolving Sustainability. Hoboken (US): John Wiley \& Sons; 2016.

29. Gibbons LV, Cloutier SA, Coseo PJ, Barakat A. Regenerative Development as an Integrative Paradigm and Methodology for Landscape Sustainability. Sustainability. 2018;10:1910. doi: 10.3390/su10061910

How to cite this article:

Pardo Abad CJ. Environmental Recovery of Abandoned Mining Areas in Spain: Sustainability and New Landscapes in Some Case Studies. J Sustain Res. 2019;1:e190003. https://doi.org/10.20900/jsr20190003 